\title{
1. Introduction: how to achieve Active Inclusion in a multi-layered political context?
}

\author{
Rune Halvorsen and Bjørn Hvinden
}

\section{INTRODUCTION}

This book asks how governments in Europe go about combating poverty and social exclusion. Poverty and social exclusion are complex problems, and a number of actors are involved in efforts to handle them. The complexity creates a range of challenges of political capacity and organization. The financial crisis that began in 2008 is an important context for the analyses presented in the book. The crisis meant that the number of people living in poverty increased dramatically in many countries and the need for financial and other assistance grew quickly. At the same time, governments' efforts to meet the crisis forced them to make substantial changes to existing social provisions, sometimes in a restrictive direction. The need to cut their budgets reduced governments' overall capacity to prevent and alleviate poverty. However, the book is not primarily about the effects of the crisis or the impact of austerity. Most of the book deals with enduring issues that most countries had faced before the early days of the crisis and that are unlikely to go away when Europe has moved beyond it.

\section{COMBATING POVERTY - THE HISTORICAL LEGACY}

Even if we do not take the words 'the poor you will always have with you' (Matthew 26:11) too literally, different forms of poverty have existed throughout Europe's recorded history. The surrounding society - and in particular those with power and property - have to different extents sought to find ways of solving the problem. Evidently, the exact ways in which authorities or communities have responded to or organized their efforts to deal with poverty have changed and developed over time. We like to think 
that measures have become humane and caring, yet there is more continuity in the ways in which societies' elites have looked at the poor and their normative frames for dealing with impoverished and destitute people than we usually acknowledge.

Strong feelings and conflicting opinions have affected the definition of poverty as concept and social phenomenon. On the one hand, religions have preached compassion for the poor and provided charity and support for them. On the other hand, poor people have often been the target of contempt, rejection and degrading treatment from those in more powerful and materially secure positions in society.

Sometimes elites or the social milieu have acknowledged that people are poor because of unfortunate circumstances such as illness, accidents, war, natural disasters or the loss of livelihood or family. At other times, the argument has been that poor people are themselves to blame for their misery because they are lazy, irresponsible and immoral. Within the emerging social science slightly more than one hundred years ago, Georg Simmel argued that not only has ambivalence dominated attitudes towards the poor; the societal position of poor people has been fundamentally ambiguous. This means that the poor were in some respects standing inside mainstream society, in other respects outside. Simmel argued that poor people usually had good reasons to hide or to be as invisible as possible in society. Only rarely did they form associations or other collectivities. Simmel concluded that, sociologically speaking, poor people only exist in so far as the surrounding society provides assistance to (or seeks to control) them, or are supposed to do so according to the norms and rules in society (Simmel, 1908). Later, Bronislaw Geremek's (1997) major study on poverty in history confirmed the deep ambivalence of the rich and those in authority about poor people in former times, as expressed in attitudes oscillating between fear and pity, revulsion and compassion.

The historically oriented sociologist Abram de Swaan (1988) has argued that the question of how elites were to handle the challenge of poor people dominated the period from the end of the Middle Ages and well into the Modern Age. De Swaan takes as his point of departure how for a long period elites perceived large numbers of impoverished or deprived people, especially those who did not belong firmly to the community but were geographically mobile, as threats to authority, property and social order. Faced with an unruly group of people who wandered from place to place, those in authority sought to differentiate between the genuinely needy and others, especially those suspected of being work-shy or simply criminal. The idea was that one should help the former, the deserving, while one should 'discipline and punish' (Foucault, 1967, 1977) the latter, the undeserving. 
Since local communities' capacity to meet the needs of the poor was limited, there was often a strong impulse to try to solve the problem by forcing flocks of poor people to move on and seek help elsewhere. However, turning away poor people just meant a circulation that at best gave temporary relief from the problem. The problem called for more collective and coordinated arrangements at a higher level of scale or for wider territories. De Swaan argues that collective efforts to overcome the off-loading of destitute people to other communities played an important role in the early formation of local authorities and eventually in the formation of more encompassing territorial entities, and, in the last instance, the modern state. De Swaan asks whether we are now seeing a new phase in this development towards collectivization of responsibilities for preventing and alleviating poverty, through European integration. In line with these classical perspectives on assistance to poor people, this book is to a considerable extent focused on the division of responsibility and the degree of coherence between the efforts of entities of different territorial scope (i.e. local, regional, national and supranational levels).

During the greater part of European history, the assistance or support given to the poor has tended to be meagre and involving subjection to strong and demeaning social control, especially for those seen as the undeserving poor. In most countries, it was first in the nineteenth century that friendly societies and other voluntary, mutual or 'self-help' forms of alternatives to degrading help and the mercy of charities started to develop to any extent. Yet de Swaan demonstrates that such alternatives often ran into problems of accumulation of 'bad risks' and simultaneous need among their members. With the firmer establishment of the modern state came also increased capacity to collect taxes and redistribute public funds based on some kind of 'politics of social solidarity' (Baldwin, 1990). In some countries, the main expression of such politics was the provision of means-tested basic support to the needy part of the population. However, the actual delivery of such support in many cases remained the responsibility of local authorities, with or without financial support from the national government.

Before and after the turn of the twentieth century, obligatory social insurance arrangements started to emerge through the nation state itself or intermediate levels such as employing, professional or voluntary organizations, with or without state mandate and state support. To the extent that they have existed and worked, social insurance arrangements have tended to reduce, but rarely completely remove, the demand for means-tested poor assistance in a number of countries.

In the first decades after the Second World War, economic reconstruction and renewal meant that many countries experienced strong growth, 
with higher rates of employment and productivity, enabling many governments to collect more taxes and expanding both the scope and generosity of income maintenance benefits and providing broader access to services (education, health and social care). In several of these countries, leading politicians declared 'the end of poverty', often as an achievement of their own political party. However, social scientists and journalists in many countries showed that this was a myth. They were able to demonstrate that, while large sections of the population had experienced remarkable improvements in living standards, there were still substantial - more or less hidden - groups who had not benefited from the general increase in affluence or material welfare.

We find considerable cross-national variation in exactly which categories of people have remained at high risk of poverty. For instance, the main categories might be old and disabled people, single mothers, people living in peripheral and depopulating rural communities, low-skilled persons becoming redundant during the restructuring of industries or never fully establishing in the regular labour market, or people of migrant or ethnic minority background experiencing discrimination (e.g. the Roma, Sinti or Sami). Anyway, through the 'rediscovery of poverty' in affluent societies, the issue of combating poverty reappeared on the political agenda from the end of the 1960s, reinforced by the effects of the restructuring of economies, and even more so by the two oil crises, meaning that economic growth decreased or stalled, and that unemployment increased again during the 1970s or 1980s.

This general development is an important context for the European Community's (and later the European Union's) growing engagement with the issue of combating poverty from the establishment of the first Poverty programme (1975-80), until the current Europe 2020 strategy with its poverty target and platform against poverty and social exclusion (see Chapters 2 and 4). Yet, as several chapters of this book indicate, many actors at national or subnational level seem to be unaware of how substantial the impact of this European engagement is. Alternatively, we may also ask whether some actors have reason to dismiss or downplay how significant the EU impact is in their country or local community. Tensions between supranational influences versus fears of loss of autonomy or national sovereignty have probably played a role in the tendency to belittle the EU impact on social policy (Leibfried, 2014). A related factor may be the competition between entities at different territorial levels in being able to take credit for good results and avoid blame for bad ones.

This book aims to provide a better understanding of the processes and mechanisms that promote or hinder interaction and exchange between levels in the emerging multi-layered European system for responding to 
poverty and social exclusion in member states. We ask what are the processes and mechanisms that create gaps between official commitments to coordinate efforts between actors and the actual practices of these actors in promoting Active Inclusion.

The empirical context for the book is a comparative case study of efforts to combat poverty and social exclusion at European, national and subnational levels, with a particular focus on Germany, Italy, Poland, Sweden and Scotland (UK). The main policy context of our analyses is the shifting and growing engagement of the EU in this area. Of particular importance here are the 2008 Recommendation on Active Inclusion, the 2010 launch of The European Platform against Poverty and Social Exclusion (as one of seven flagship initiatives of the Europe 2020 strategy for smart, sustainable and inclusive growth), and the 2013 Social Investment package. As all these initiatives aim to stimulate active and coordinated efforts in member states, they illustrate the challenges of multi-level and multi-actor governance.

\section{HOW TO UNDERSTAND DECISION-MAKING AND IMPLEMENTATION IN COMPLEX SYSTEMS?}

Over the past couple of decades we have seen a growing interest in policymaking and implementation taking place through vertical and horizontal relationships in multi-layered and multi-actor policy contexts. A substantial part of the scholarship on these topics is a direct response to major challenges facing decision-makers at supranational, national and subnational levels in contemporary Europe. Drawing on this scholarship, we outline an analytical framework as a backdrop for the contributions to the book. The framework centres on the diverse and interrelated mechanisms that enhance, or impede, policy coordination, effective multi-level governance, involvement of stakeholders, and collaboration between actors at different or the same territorial levels. Overall, the book is an examination of how fruitful are approaches framed in terms of multi-level and network governance and inter-organizational coordination in relation to the specific issue of combating poverty and social exclusion in contemporary Europe.

\section{FROM GOVERNMENT TO GOVERNANCE?}

A long tradition of the social sciences (especially political science, political and organizational sociology) has theorized the decision-making, implementation and actor-structure relations in hierarchical systems. This theorization has usually built on ideal-type concepts such as the modern state's 
monopoly of legitimate use of force and of collecting taxes, the legitimate power of democratically elected decision-makers, including their delegation of authority to administrative staff to exercise power on their behalf. This conceptualization implies a chain of authority and implementation from the top to the bottom of hierarchies. Related to this conceptualization are also ideas of what characterizes the typical development of the state in modern and affluent societies. As already mentioned, one of these ideas is that long periods of economic growth have enabled the modern central state to go beyond basic public provision of, say, military defence and law enforcement and to offer a range of tax-funded services (health, education etc.) and income maintenance through cash transfers.

Against such a simplified picture, one might argue that, in practice, we find considerable variation over time and space in what degree of delegated authority or relative autonomy regional and local governments have enjoyed $v i s-\grave{a}$-vis the central government. A strand of research has even suggested that the relative autonomy of subordinate agencies and front-line staff in public services has enabled them to some extent to 'make policy' through their daily practices (e.g. Lipsky, 1980). Another argument has been that public governments - to varying extents over time and space - have drawn non-public actors and entities into forums for discussing and seeking broad consensus on aspects of policy, for instance related to economic policy, to labour market or to social issues. Such forums have been of a more or less corporatist nature. Finally, some would add that, despite an increasing role for publicly provided and tax-funded services, in most countries voluntary, the contribution of civil society or market-based entities has continued to complement or even substitute for public provision.

More recently, a number of observers have claimed that we need to leave behind or at least moderate the assumption about a dominant central (nation) state with strong steering and regulatory capacity (Pierre and Peters, 2000; Bache and Flinders, 2004; Enderlein et al., 2010; Stephenson, 2013). One argument for this claim is that stronger global competition, changing demographic composition and a more volatile international economic situation have reduced the central state's possibility to increase or even uphold tax levels. Hence, the state is becoming more dependent on resources or inputs controlled by non-public entities to deal with an expanding range of tasks or to contribute to solving pressing problems.

A second argument is that the emergence of new and complex issues requires the sharing of capacity, knowledge and competence, calling for mutual adjustment, negotiation, coordination and collaboration between public and private actors and across different sectors and territorial levels. Such issues could be increasing disparity in the economic development and affluence of a country's regions, insufficient or 
uneven scientific and technological innovation, climate change, global warming and environmental degradation, new threats to inhabitants' security, health and well-being, and the persistence of poverty, social exclusion, skill deficit and unemployment among substantial groups. In line with this, we can interpret the EU Commission's 2008 Active Inclusion approach and its 2013 Social Investment package as responses to intractable and complex issues in Europe, both calling for vertical as well as horizontal coordination of efforts (European Commission, 2008, 2013).

A third argument refers to the growing significance of the supranational level through the economic integration of Europe and the decision-making, monitoring, law enforcement and judiciary processes, policy coordination and mutual learning taking place within the context of the EU. While the European Council consists of ministers from member state governments, for an increasing number of issues it has to reach an agreement with the directly elected European Parliament, including the appointment of the Commission's president. The Commission has come to play a key role in the development of proposals for new policy and legislation for the Union. In some areas, for instance the Structural Funds, European bodies are in a position to interact directly with and provide support to entities at subnational levels. All these factors have increased the interdependencies between the European and national levels and between member states.

Based on these and similar arguments, many scholars conclude that the sovereignty, regulatory power and steering capacity of the central nation state have weakened. They claim that some of the state's traditional decision-making power has dispersed upwards to the European level and downwards to the subnational level, creating room for "political rule beyond hierarchical authority and subordination' (Olsen, 2010, p. 56). As a result, decision-makers at the national level have a greater need to engage in processes of discussion and negotiation (1) with authorities at subnational or supranational levels and (2) with non-public actors and entities, for the purpose of reaching agreements on political goals and ways to achieve them, sharing information, mobilizing resources and coordinating practical efforts. Such less authoritative and directive processes of policymaking, regulation, coordination and implementation are at the core of 'governance', as we use the concept here.

Governance has a vertical as well as a horizontal dimension. To simplify, one can say that, to the extent that we focus on the vertical dimension - the processes of discussion and negotiation to achieve consensus, coordinated efforts or collaboration of actors (entities) across different territorial levels - we are dealing with 'multi-level governance'. Conversely, if we consider the horizontal dimension - similar processes between actors (or entities) operating at more or less the same territorial level - we are addressing 
'network governance' (e.g. Querejeta et al., 2008; Klijn and Koppenjan, 2012; Sørensen and Torfing, 2006). In practice, the distinction between vertical and horizontal governance may be less clear-cut, partly because coordination and collaboration may involve actors at different territorial levels, partly because they may depend on contextual or situational factors that turn out to be the dominant partner in a given process or emergent governance arrangement.

A rich and many-faceted body of theory and empirical research on multi-actor and inter-organizational relations and policy networks has paved the way for current studies of network governance. By contrast, the concept of multi-level governance has a history of only a couple of decades, and research based on it is still under rapid development. Most scholars see Gary Marks (1993) as the first to coin the term 'multi-level governance' and then in the context of research on EU structural or regional policy. Together with Liesbet Hooghe, Marks subsequently published a series of theoretical and empirical studies mostly focused on multilevel governance in the European context (e.g. Hooghe and Marks, 2003; Marks and Hooghe, 2004). While the analysis of multi-level governance has widened to include both issues of global policy coordination and intranational policy integration and coherence, studies related to development in the EU still play a dominant role.

\section{MULTI-LEVEL GOVERNANCE - A GUIDE FOR A WELL-FUNCTIONING EU?}

Significantly, some parts of the EU apparatus quickly embraced concepts of governance and, more specifically, of multi-level governance, and adopted them as means to define the desirable future functioning of the EU. For instance, in its 2001 White Paper on European Governance, the Commission took as its point of departure that many European citizens experienced disenchantment, distrust and distance vis-à-vis the EU. The Paper outlined how aspects of governance could open up the European policy-making process to get more people and organizations involved. The EU was to achieve this goal, among other steps, by stronger direct interaction and systematic dialogue between the EU and regional and local governments and civil society in member states (i.e. through multi-level governance).

The Commission defined governance as 'rules, processes and behaviours that affect the way in which power is exercised at European level, particularly as regards openness, participation, accountability, effectiveness and coherence' (European Commission, 2001, p. 5, footnote). The Commission 
expressed great confidence in the potential gains of improved governance, as well as in the commitment to 'concerted action by all the European institutions, present and future Member States, regional and local authorities and civil society' (ibid., p. 6), to make this a reality. While the Commission required a 'multi-level partnership' in which national governments involve their regions and cities fully in European policy-making (ibid., p. 9), the Union must also build its own partnerships and rely on a wide variety of actors (ibid., p. 27). The final vision of the Paper was 'a Union based on multi-level governance in which each actor contributes in line with his or her capabilities or knowledge to the success of the overall exercise' (ibid., p. 29).

While the notion of multi-level governance had faded off the screen when the Commission (2003) presented its follow-up report on European governance, the EU Committee of the Regions (CoR) in particular picked up multi-level governance and became a strong promoter of the concept. CoR published a White Paper on multi-level governance in 2009 (CoR, 2009) and a follow-up in 2012 (CoR, 2012). In 2014, CoR adopted a Charter for Multi-level Governance in Europe (CoR, 2014) and launched a campaign for signatures to the Charter. The 2009 White Paper in particular has strong normative undertones, arguing for instance that multilevel governance must be based on 'mutual loyalty between all the various levels of government and the institutions to reach common goals' (CoR, 2009 , p. 8). Moreover, a comparison of the Commission's definition of multi-level governance with CoR's definitions makes it clear that the latter shifted towards a stress on subsidiarity and proportionality, that is, respect for the distinct functions of regional and local governments. In 2009, CoR defined multi-level governance as

coordinated action by the European Union, the Member States and local and regional authorities, based on partnership and drawing up and implementing EU policies. (CoR, 2009, p. 5)

A few years later, the CoR had consolidated this definition:

coordinated action by the EU, the Member States and regional and local authorities according to the principles of subsidiarity, proportionality and partnership, taking the form of operational and institutionalised cooperation in the drawing-up and implementation of the European Union's policies. (CoR, 2014, p. 3)

Overall, this short review of EU engagement with the concept of multi-level governance demonstrates that it has had both descriptive and normative uses within the EU system, partly to highlight steps to open up and involve 
more diverse actors and entities in EU policy-making, and partly to signal normative expectations about the other actors' commitment and loyalty. The documents reviewed here assign the most explicit role for multi-level governance in relation to implementing cohesion, environment and energy policies, and, in general terms, a role in implementing the Europe 2020 flagship initiatives. Interestingly, the European Commission has initiated and funded a project specifically focused on what role multi-level governance can play in ensuring the success of the Europe 2020 strategy (Böhme et al., 2013). One of the areas for case studies in the project is the role of multi-level governance in promoting social inclusion in urban areas (ibid., pp. 49-59).

However, until the second decade of the 2000s, EU policy documents made relatively few explicit references to multi-level governance as a means to fight poverty and social exclusion. In this area, the favoured concept from the early 2000s was 'the open method of coordination' (OMC). A key element of the OMC has been the setting of common European objectives, supported by guidelines, national action plans, peer reviews, joint evaluation reports, recommendations and mutual learning. While the $\mathrm{OMC}$ was not designed to lead to binding decisions, underpinned by legal enforcement, it offered various incentives for national actors to comply with recommendations (e.g. Ferrera et al., 2002; Heidenreich, 2009). Arguably, the OMC has in practice involved elements of multi-level governance, for instance through the involvement of various stakeholders in the formulation of national action plans and the European-level reviews of national plans and achievements. Yet surprisingly few of the key researchers on OMC seem to have been interested in the concepts of multi-level or network governance. Some of the prominent researchers on the OMC have explicitly preferred conceptual labels such as constructive and experimentalist governance (e.g. Sabel and Zeitlin, 2008; Zeitlin et al., 2014).

On the other hand, there are also reasons to ask to what extent researchers framing their analyses in terms of multi-level or network governance have engaged with the policy field of poverty and social exclusion.

\section{THE SCHOLARSHIP ON MULTI-LEVEL GOVERNANCE - CONCERNED WITH THE FIGHT AGAINST POVERTY?}

Given what we have already said about the origin of the concept of multilevel governance, it is not surprising that we find the greatest number of studies adopting the concept in the field of regional, cohesion or structural 
EU policy (see Stephenson, 2013 for an overview). While the European Social Fund in particular is highly relevant for the fight against poverty and social exclusion (Allen, 2005; Verschraegen et al., 2011), until recently few publications analysing EU regional policy had brought out this aspect. With the impressive study 'The Territorial Dimension of Poverty and Social Exclusion in Europe' (TiPSE, 2014), under the ESPON programme, this is likely to change.

However, other frequent contexts for the analysis of multi-level governance are environment policy (Fairbrass and Jordan, 2004; Kern and Bulkeley, 2009; Wälti, 2010) and economic policy (Perraton and Wells, 2004; Enderlein, 2010).

More generally, many publications have analysed the horizontal relationships between actors, organizations and other entities in the broad field of welfare or social services, starting in the early 1960s (see Cropper et al., 2008 for an extensive review of this scholarship). More recently, this strand of research has also analysed efforts to combat poverty and social exclusion, for instance through better coordination between public agencies, public-private partnerships and other forms of collaborative governance arrangements (e.g. van Berkel et al., 2011; Popp et al., 2013). Comparatively few publications have systematically investigated vertical or multi-layered linkages between actors, organizations or governments in the domain of fighting poverty and social exclusion. To the extent that such studies exist, they have investigated linkages between actors and organizations at different territorial levels. Some studies have focused on linkages between the EU and national governments (e.g. Ferrera, 2005; Frazer and Marlier, 2013; Sabel and Zeitlin, 2008), between national and subnational governments (e.g. Graser and Kuhnle, 2010). A few studies have dealt with relationships between the EU - particularly through the European Social Fund - and subnational levels of member states (e.g. Burgoon, 2010; López Viso, 2010; López Viso and Fernández Álvarez, 2014; Vranken, 2010). Others have addressed the shifting division of responsibility for poverty alleviation measures (e.g. minimum income arrangements and related social services) between actors or entities at different territorial levels (e.g. Mabbett and Bolderson, 1998; Kazepov, 2010; Kazepov and Barberis, 2013).

Given the paucity of research on efforts to combat poverty and social exclusion in the multi-level and multi-actor European context, the ambition of this book is to contribute to further theoretical development in this area, building on new empirical knowledge about the nature of vertical and horizontal linkages in such efforts. Our aim is not only to describe comparatively the degree of collaboration between actors within given territorial entities (e.g. partnerships or co-production in a given local context) 
or the degree of coordinated aims and efforts between entities at different territorial levels (e.g. between the EU Commission and the government of a member state). We also seek to provide new insight into why policy coordination and collaboration work well in some instances and less well in others. For this reason, the analytical framework of the book incorporates assumptions about what kind of circumstances, processes or mechanisms promote, or hinder, collaboration, partnership or coordination, as achieved in practice. Here, we are also building on existing theorization and findings in different strands of earlier research, especially in the scholarship on inter-organizational relations and multi-level and network governance, but with the aim of moving beyond the state of the art in these and related fields of scholarship.

\section{ELEMENTS OF AN ANALYTICAL FRAMEWORK}

As a first step, we consider what practical expressions multi-layered and multi-actor governance might take. We have already indicated that a common idea in the literature on such aspects of governance is that no particular level of government, for instance the central (nation) state, is sovereign and fully able to oversee and control what happens in its territory. Greater complexity of issues and institutional patterns is supposed to mean that decision-making capacity diminishes or disperses:

- At each territorial level, public authorities need to engage in discussion to establish various forms of networks, agreements, alliances or collaboration with non-public actors at the same level. While a public authority may be a dominant partner in such networks, it still needs the participation, resources and legitimacy of others to ensure or improve its capacity to achieve significant goals.

- Public authorities are not only dependent on other actors at the same territorial level, but are also influenced and constrained by authorities and actors at other levels (e.g. supranational, national, regional, local or individual, as the case may be). Conversely, public authorities at a given territorial level are likely to seek to influence and constrain the actions of authorities and actors at the other levels. These interdependencies and the actors' responses will probably generate more or less open tensions.

Such efforts are, under some conditions, likely to create a web of dynamic relationships characterised by negotiation, manoeuvring, coalition or alliance building and mutual adjustment - but not necessarily in 
all circumstances. In general, we expect important dimensions of these relationships to include:

- relations of power (expressed in dominance and authority but also in conflict strategies of coping, avoidance, evasion or resistance);

- flows of resources (authority, material and symbolic resources, associated with emergent dependencies and networks of exchange);

- symbolic struggles (for recognition, respect, loyalty, trust and worthiness);

- actors' ways of coping with potential strain and tension (related to asymmetries in power, control over resources, status, as well as capacity to define the status and symbolic capital of others).

First, on the dynamics of power and exchange relations an important inspiration is the work of Richard Emerson (1962) and James Coleman (1990, pp. 132-3). Using an Emerson-Coleman perspective, we can see power as an aspect of exchange relations. A key question is whether two actors both control resources that are of interest or value for the other. To the extent that both actors control such resources, there is mutual dependence and a basis for reciprocal and balanced exchange. However, if one actor controls resources of interest or value for the other, but not vice versa, the dependence will be unilateral and the exchange will be unequal or will not take place. This situation involves a potential power imbalance and/or a relationship of latent tension or open conflict.

Second, Bloor and McIntosh (1990) have provided an interesting example of the use of a Foucault-inspired analysis of resistance on the part of recipients of social and health services. Through two qualitative case studies, they identified some main types of resistance to what people perceived as attempts of supervisory surveillance and control of their lifestyle and daily behaviour:

- Collective ideological dissent

- Individual ideological dissent

- Non-cooperation

- Concealment

According to a review of earlier research, many authors converged on stressing three main conditions for integration of efforts across levels of governance and agencies operating at the same level (Hvinden, 1994): These conditions included: (1) mutual awareness and recognition between key players; (2) compatibility of perceptions and goals; and (3) perceived scope for interdependence and reciprocal exchange of resources. 
Moreover, this scholarship had identified a number of coping mechanisms adopted in cases of one dominant actor and unilateral dependence. A comparative study of horizontal relations between social insurance and social services agencies in Norway and Scotland found that lower-level staff's unease about the contrasts in agencies' policy mandates and organizational ideologies, operational goals and priorities, and risks of infringements in their own autonomy often meant that they adopted one or several forms of defensive adjustments (Hvinden, 1991, 1994):

- self-containment (e.g. active efforts to 'do without' the resources that the other agency was supposed to provide and attempts to replace these with in-house resources);

- evasion of expectations about collaboration and requests for resources from the other agency;

- avoidance of direct contact with representatives of the other agency;

- protection of own resources by off-loading demanding tasks to other agencies (e.g. irregular referral of claimants or clients).

The practical scope for adopting such adjustments obviously depended on the de facto relative autonomy and discretion enjoyed by lower-level staff and the extent to which superiors regularly monitored their daily work (Lipsky, 1980). Yet, to the extent that staff were able to adopt the strategies, they served as a mechanism for playing down the significance of the policy goals that mandated coordination and collaboration between the agencies would supposedly promote. Moreover, at an aggregate level the strategies functioned as a mechanism to limit the amount of coordination and collaboration between agencies that happened in practice.

Third, according to Anthony Giddens (1984), a social system is a set of reproduced social practices and relations between actors. Social systems are relatively bounded social practices that link persons across time and space. In other words, they are reproduced social interaction patterns. The focus on the 'systemness' of social practices allows us to examine the relations between different loosely coupled practices. When analysing the 'systemness' of policies to prevent and alleviate poverty, we are interested in how social entities seen as wholes, comprising interacting components, are operating in and co-evolving with their environment. When viewing policies to prevent poverty and promote inclusion as a system, we are interested in the relations between the entities or subsystems; that is, to what extent the policy measures and actors are coordinated, support or contradict each other, and how they evolve within their environment. While, from a system perspective, we may focus on the relations between the policies and practices that by design or default influence the quality 
of life and opportunities for participation, we need to focus on agency to examine how interaction of relevant actors influences the outcome of the policy measures. If we viewed policies for preventing and alleviating poverty only from a system perspective (or as a social system), we would run the risk of viewing the policy design as a mere 'technical' problem of administrative coordination between policy measures or 'technicization' of politics. In such cases, we would risk ignoring how actors' reasoning and purposeful action influence policies to prevent and alleviate poverty and their outcomes. Not only do the actors have different and sometimes conflicting interests and values; they also have unequal access to symbolic, social and economic resources to pursue their interests. Recently, Rob Stones's analytical elaboration has facilitated the methodological applicability of Giddens's theory (Stones, 2005; see also O'Reilly, 2012).

This book will build on these theories and related empirical findings on power and exchange relations, the active agency of the parties involved, and possible strategies of resistance, evasion and similar adjustments to latent tension and conflict. We use the theories and findings as inspiration for clarifying the processes and mechanisms that effectively promote or prevent the scope of coordination and collaboration between relevant actors and across territorial levels in the fight against poverty and social exclusion. In our analyses of how such processes and mechanisms hamper or enhance effective arrangements for combating poverty and social exclusion, we seek to identify the underlying actor-structure dynamics. By such dynamics, we refer to the ways in which structural conditions - both external and internal to an actor - serve as barriers as well as facilitators of active agency. Furthermore, in some instances, collective agency in particular may change external and internal structures (see Stones, 2005 and O'Reilly, 2012 for elaboration of such dynamics). Our aim is to identify the significant and relevant kinds of resource in each case, and the actual patterns of control over resources, exchange and power relations and strategies of coping or adjustment we find here. In combination, information on these aspects will help us understand differences and similarities in the observed practices and approaches in combating poverty and social exclusion in multi-level and multi-actor contexts.

With this general framework as a backdrop, the chapters of the book investigate the contemporary challenges of policy and governance related to combating poverty and social exclusion. These challenges face many European countries, albeit in different ways and degrees. An important rationale for the book is a belief in the value of systematic cross-national comparison as a means to sharpen awareness of one's own country's particular characteristics and challenges. Such a comparison also contributes to a better understanding of factors and mechanisms at work 
across territorial levels and national contexts, and identifying potentials for inspiration, learning or emulation. A better and more informed understanding is not only a goal in itself; it will also serve as a basis for clarifying policy options and possible recommendations for policy-makers at both European and national levels.

\section{THE SCOPE AND DESIGN OF THE COPE PROJECT}

This book presents results of the project 'Combating Poverty in Europe: Re-organizing Active Inclusion through Participatory and Integrated Modes of Multilevel Governance' (COPE), under the seventh framework programme of the EU and coordinated by the Carl von Ossietzky University Oldenburg (CETRO), Germany. COPE has investigated how five countries (Germany, Italy, Poland, Scotland (UK) and Sweden) have sought to combat poverty and social exclusion and what role the EU's Active Inclusion approach and related governance arrangements have played in these efforts. More broadly, the project has studied to what extent coherence, coordination and cooperation have been achieved in and across diverse territorial levels (European, national and subnational) in the fight against poverty and social exclusion. The project is unique as it has collected data on efforts to combat poverty and exclusion at several territorial levels and the impact of such efforts on the diverse life courses of individuals belonging to deprived groups (and, more specifically, to three target groups: lone mothers; long-term unemployed people; and working poor people). The data include quantitative survey data, documents, expert interviews and life-course interviews with people who have experienced poverty and belong to one of the three target groups.

First, the design of the project permits us to compare the governance and organization of efforts and their substance and accomplishments at each of these territorial levels. Since poverty and social exclusion are multifaceted problems, their alleviation often calls for multidimensional, multiactor and coordinated approaches. Such approaches may combine income support, employment assistance and relevant social and health services. The project has investigated the extent to which national and subnational governments in the five countries have adopted such approaches and what their practical achievements have been. COPE has focused on these specific countries to obtain variation in the societal arrangements and the relative roles of the key institutions believed to be important for combatting poverty and exclusion (i.e. public authorities, business organizations, families and voluntary associations).

Second, the design of the project allows us to examine the inter- 
relationships and degrees of coherence of policy approaches across different territorial levels. As policies to combat poverty and exclusion must be initiated, adopted, supported and pursued by relevant actors to have practical significance, the project has also sought to clarify actors' ideas, perceptions and opinions, the actual steps they take, and how they relate to each other. Indeed, the project has carried out interviews with a number of these relevant actors or stakeholders at the different territorial levels. Together with available policy documents and statements, these interviews provide important insights into the mechanisms that lead to higher, or lower, policy coherence, common strategies and coordinated efforts across territories.

Finally, the choice of countries covered in the COPE project provides for cross-national variation and comparison along several dimensions of multi-level and multi-actor (network) governance, such as:

- lateral policy coordination: the degrees of coherence and forms of coordination across different policy fields (e.g. between minimum income protection, employment policy, the provision of high-quality health and social services);

- multi-level governance: the modes of vertical organization and coordination (e.g. the respective roles of central, regional and local governments in deciding on and/or regulating the substance and forms delivery of services of relevance for active inclusion);

- horizontal collaboration: the nature of relations and degree of joint efforts between actors representing different public providers (e.g. mandated integration, bridging institutions or discretionary loose couplings), and between public, private market-based and notfor-profit and ideal-driven actors (e.g. establishment of networks, agreements (compacts), formalized partnerships, contractualisation, outsourcing), at each territorial level.

Overall, the richness of the COPE design and data allows for a unique, systematic and comprehensive analysis of issues of key importance in contemporary Europe.

\section{THE STRUCTURE OF THE BOOK}

The rest of the first part of the book will review how different ways of understanding poverty and social exclusion to different extents involve multidimensional challenges for policy and governance (Chapter 2). Chapter 3 discusses how measuring poverty and exclusion poses a statistical 
challenge, with particular emphasis on how the spatial patterns of poverty and exclusion in Europe call for more differentiated and context-sensitive policies. Chapter 4 reviews how poverty and social exclusion over time have emerged as increasingly important arenas in the EU.

Part II investigates the developing of a multi-level system for prevention and alleviation of poverty and social exclusion from a national perspective. Chapter 5 discusses the role of institutional arrangements for policy coordination in national anti-poverty regimes. Chapter 6 analyses and compares more specifically the provisions aimed at lone mothers, the long-term unemployed and working poor in the five countries under study, while Chapter 7 analyses in detail the implementation of the Europe 2020 anti-poverty element at the national level.

Part III examines the multi-level system from a subnational angle. Chapter 8 analyses and compares the approaches, actors and models of collaborative governance in combating poverty in five cities (one from each of the countries under study). Chapter 9 studies more thoroughly how local actors relate to the policies, steering mechanisms and resources of higher-level entities. Chapter 10 focuses on the perspectives and experiences of members of the three (overlapping) target groups of antipoverty policies (lone mothers, the long-term unemployed and working poor).

Finally, the Chapter 11 draws together the main findings with reference to the analytical framework outlined here.

\section{REFERENCES}

Allen, David (2005), 'Cohesion and the structural funds: competing pressures for reform?', in Helen Wallace, William Wallace and Mark A. Pollack (eds), Policy-Making in the European Union, 5th edn, Oxford: Oxford University Press, pp. 213-14.

Bache, Ian and Matthew Flinders (eds) (2004), Multi-level Governance, Oxford: Oxford University Press.

Baldwin, Peter (1990), The Politics of Social Solidarity: Class Bases of the European Welfare State 1975-1975, Cambridge: Cambridge University Press.

Bloor, Michael and James McIntosh (1990), 'Surveillance and concealment: a comparison of client resistance in therapeutic communities and health visiting', in Sarah Cunningham-Burley and Neil P. McKeganey (eds), Readings in Medical Sociology, London: Routledge, pp. 159-81.

Böhme, Kai, Sabine Zillmer, Sofie Jæger and Frank Holstein (Spatial Foresight) and Lisa Hörnström, Alex Bubois and Stephanie Lange-Scherbenske (NordRegio) (2013), Inception Report: Study of Promoting Multilevel Governance in Support of Europe 2020, Brussels: European Commission, Directorate General on Regional and Urban Policy. 
Burgoon, Brian (2010), 'Betwixt and between? The European Union's redistributive management of globalization', Journal of European Public Policy, 17 (3), 433-48.

Coleman, James S. (1990), Foundations of Social Theory, London: The Belknap Press of Harvard University Press.

CoR (2009), Opinions, Committee of the Regions, 80th plenary session 17 and 18 June 2009, Committee of the Regions' White Paper on Multilevel Governance, Official Journal of the European Union, C211/1-27.

CoR (2012), Opinion of the Committee of the Regions on 'building a European culture of multilevel governance: follow-up to the Committee of the Regions' White Paper', Official Journal of European Union, C 113/62-72.

CoR (2014), Charter for Multilevel Governance in Europe, COR-2014-01728-0000-RES-TRA (accessed 10 June 2014 at https://portal.cor.europa.eu/mlgcharter/ Pages/MLG-charter.aspx).

Cropper, Steve, Mark Ebers, Chris Huxham and Peter Smith Ring (eds) (2008), Oxford Handbook of Inter-Organizational Relations, Oxford: Oxford University Press.

De Swaan, Abram (1988), In Care of the State: Health Care, Education and Welfare in Europe and the USA in the Modern Era, Cambridge: Polity.

Emerson, Richard (1962), 'Power-dependence relations', American Sociological Review, 27 (1), 31-41.

Enderlein, Henrik (2010), 'Economic policy-making and multi-level governance', in Henrik Enderlein, Sonja Wälti and Michael Zürn (eds), Handbook of MultiLevel Governance, Cheltenham, UK and Northampton MA, USA: Edward Elgar, pp. 423-40.

Enderlein, Henrik, Sonja Wälti and Michael Zürn (eds) (2010), Handbook of MultiLevel Governance, Cheltenham, UK and Northampton MA, USA: Edward Elgar.

European Commission (2001), European Governance - a White Paper, COM(2001) 428 final, Official Journal of the European Communities, C278/1-29.

European Commission (2003), Report from the Commission on European Governance, Luxembourg: Office for Official Publications of the European Communities.

European Commission (2008), Recommendation of 3 October 2008 on the active inclusion of people excluded from the labour market (2008/867/EC) (accessed 10 June 2014 at http://eurlex.europa.eu/LexUriServ/LexUriServ.do?uri=COM:201 3:0083:FIN:EN:PDF).

European Commission (2013), Communication of 20 February 2013, Towards Social Investment for Growth and Cohesion - including implementing the European Social Fund 2014-2020 (COM(2013) 83 final) (accessed 10 June 2014 at http://ec.europa.eu/social/main.jsp?catId=1044\&).

Fairbrass, Jenny and Andrew Jordan (2004), 'Multilevel governance and environmental policy', in Ian Bache and Matthew Flinders (eds), Multi-level Governance, Oxford: Oxford University Press, pp. 147-64.

Ferrera, Maurizio (2005), 'Contested social sovereignty: welfare states meeting the European Union', in M. Ferrera (ed.), The Boundaries of Welfare: European Integration and the New Spatial Politics of Social Protection; Oxford: Oxford University Press, pp. 111-66.

Ferrera, Maurizio, Manos Matsaganis and Stefano Sacchi (2002), 'Open coordination against poverty: the new EU "social inclusion process", Journal of European Social Policy, 12 (3), 227-39. 
Foucault, Michel (1967), Madness and Civilization: A History of Insanity in the Age of Reason, London and New York: Tavistock/Routledge.

Foucault, Michel (1977), Discipline and Punish: The Birth of the Prison, London: Penguin Books.

Frazer, Hugh and Eric Marlier (2013), Assessment of the Implementation of the European Commission Recommendation on Active Inclusion: Study of National Policies, Network of Independent Experts on Social Inclusion, European Commission, Luxembourg: Publication Office of European Union.

Geremek, Bronislaw (1997), Poverty: A History, Oxford: Blackwell Publishers.

Giddens, Anthony (1984), The Constitution of Society: Outline of the Theory of Structuration, Cambridge: Polity.

Graser, Alexander and Stein Kuhnle (2010), 'Social policy and multi-level governance', in Henrik Enderlein, Sonja Wälti and Michael Zürn (eds), Handbook of Multi-Level Governance, Cheltenham, UK and Northampton MA, USA: Edward Elgar, pp. 399-410.

Heidenreich, Martin (2009), 'The open method of coordination: a pathway to the gradual transformation of national and employment regimes?', in Martin Heidenreich and Jonathan Zeitlin (eds), Changing European Employment and Welfare Regimes, London and New York: Routledge, pp. 10-36.

Hooghe, Liesbet and Gary Marks (2003), 'Unravelling the central state, but how? Types of multi-level governance', American Political Science Review, 97 (2), 233-43.

Hvinden, Bjørn (1991), 'Interorganisational relations in the pursuit of social security', in Michael Adler, Colin Bell, Jochen Clasen and Adrian Sinfield (eds), The Sociology of Social Security, Edinburgh: Edinburgh University Press, pp. 249-64.

Hvinden, Bjørn (1994), Divided Against Itself. A Study of Integration in Welfare Bureaucracy. Oslo: Scandinavian University Press.

Kazepov, Yuri (ed.) (2010), Rescaling Social Policies: Towards Multilevel Governance in Europe, Farnham, UK: Ashgate.

Kazepov, Yuri and Eduardo Barberis (2013), 'Social assistance governance across Europe: towards multilevel perspectives', in Ive Marx and Kenneth Nelson (eds), Minimum Income Protection in Flux, Basingstoke, UK: Palgrave Macmillan, pp. 217-48.

Kern, Kristine and Harriet Bulkeley (2009), 'Cities, Europeanization and multilevel governance: governing climate change through transnational municipal networks', Journal of Common Market Studies, 47 (2), 309-22.

Klijn, Eric Hans and Joop Koppenjan (2012), 'Governance network theory: past, present and future', Policy and Politics, 40 (4), 187-206.

Leibfried, Stephan (2014), 'Social policy: left to the judges and the markets?', in Helen Wallace, Mark A. Pollack and Alastair R. Young (eds), PolicyMaking in the European Union, 7th edn, Oxford: Oxford University Press, pp. 263-92.

Lipsky, Michael (1980), Street-Level Bureaucracy, New York: Russell Sage Foundation.

López Viso, Mónica (2010), 'The social dimension of European cohesion policy in a 27-state Europe: an analysis of the European Social Fund', European Journal of Social Work, 3 (13), 1369-457.

López Viso, Mónica and Antón Lois Fernández Álvarez (2014), 'Multi-level governance and social cohesion in the European Union. The assessment of local 
agents: a study case inside Galicia', Revista Brasileira de Politica Internacional, 57 (2), 196-213.

Mabbett, Deborah and Helen Bolderson (1998), 'Devolved social security systems: principal-agent versus multilevel governance', Journal of Public Policy, 18 (2), 177-220.

Marks, Gary (1993), 'Structural policy and multilevel governance in the EC', in Alan W. Cafruny and Glenda Rosenthal (eds), The State of the European Community, Vol. 2: the Maastricht Debates and Beyond, Boulder, CO: Lynne Rienner, pp. 391-410.

Marks, Gary and Liesbet Hooghe (2004), 'Contrasting visions of multilevel governance', in Ian Bache and Matthew Flinders (eds), Multi-level Governance, Oxford: Oxford University Press, pp. 15-30.

Olsen, Johan P. (2010), Governing Through Institution Building: Institutional Theory and Recent European Experiments in Democratic Organization, Oxford: Oxford University Press.

O'Reilly, Karen (2012), International Migration and Social Theory, Basingstoke, UK: Macmillan.

Perraton, Jonathon and Peter Wells (2004), 'Multi-level governance and economic policy', in Ian Bache and Matthew Flinders (eds), Multi-level Governance, Oxford: Oxford University Press, pp. 179-94.

Pierre, Jon and B. Guy Peters (2000), Governance, Politics and the State, Basingstoke, UK: Palgrave Macmillan.

Popp, Janice K., Gail MacKean, Ann Casebeer, H. Brinton Millward and Ronald Lindstrom (2013), Interorganizational Networks: A Critical Review of the Literature to Inform Practice, Alberta: Alberta Centre for Child, Family \& Community Research.

Querejeta, Mari Jose Aranguren, Cristina Iturrioz Landart and James R. Wilson (eds) (2008), Networks, Governance and Economic Development, Cheltenham, UK and Northampton MA, USA: Edward Elgar.

Sabel, Charles F. and Jonathan Zeitlin (2008), 'Learning from difference: the new architecture of experimentalist governance in the EU', European Law Journal, 14 (3), 271-327.

Simmel, Georg (1908), 'Der Arme', in Georg Simmel, Soziologie: Untersuchungen über die Formen der Vergesellschaftung, Berlin: Duncker \& Humblot, 1908 (1. Auflage), Kap. VII (S. 345-74).

Sørensen, Eva and Jacob Torfing (eds) (2006), 'Introduction - governance network research: toward a second generation', in Theories of Democratic Network Governance, Basingstoke, UK: Palgrave Macmillan, pp. 1-21.

Stephenson, Paul (2013), 'Twenty years of multilevel governance: "Where does it come from? Where is it? Where is it going?"', Journal of European Public Policy, 20 (6), 817-37.

Stones, Rob (2005), Structuration Theory, Basingstoke, UK: Palgrave Macmillan.

TiPSE (2014), The Territorial Dimension of Poverty and Social Exclusion in Europe, Applied Research 2013/24, Final Report, the ESPON Programme (accessed 24 June 2015 at http://www.espon.eu/main/Menu_Projects/Menu_ AppliedResearch/tipse.html).

Van Berkel, Rik, Willibrord de Graaf and Tomáš Sirovátka (eds) (2011), The Governance of Active Welfare States in Europe, Basingstoke, UK: Palgrave Macmillan.

Verschraegen, Gert, Bart Vanhercke and Rika Verpoorten (2011), 'The European 
Social Fund and domestic activation policies: Europeanization mechanisms', Journal of European Social Policy, 21 (1), 55-72.

Vranken, Jan (2010), 'Combating poverty and social exclusion through labour market participation - a role for the ESF?', Background paper for ESF Conference, 18-19 November, Brussels (accessed 9 June 2014 at www.mi-is.be/sites/default/ files $/ \mathrm{doc} / 3 \% 20-\% 20$ Vranken $\% 20-\% 20$ role $\% 20$ of $\% 20$ the $\% 20 \mathrm{ESF}^{2} \% 20 \mathrm{in} \% 20$ combating $\% 20$ poverty.pdf).

Wälti, Sonja (2010), 'Multi-level governance environmental governance', in Henrik Enderlein, Sonja Wälti and Michael Zürn (eds), Handbook of Multi-Level Governance, Cheltenham, UK and Northampton MA, USA: Edward Elgar, pp. 411-22.

Zeitlin, Jonathan, Egidijus Barcevicius and J. Timo Weishaupt (2014), 'Institutional design and national influence of EU social policy coordination: advancing a contradictory debate', in Egidijus Barcevicius, J. Timo Weishaupt and Jonathan Zeitlin (eds), Assessing the Open Method of Coordination: Institutional Design and National Influence of EU Social Policy Coordination, Basingstoke, UK: Palgrave Macmillan, pp. 1-15. 